\title{
EFEK EKSTRAK ETANOL BIJI JAGUNG (ZEA MAYS) TERHADAP PROFIL LIPID TIKUS WISTAR DENGAN DIET TINGGI LEMAK
}

\author{
Ni Luh Rustini*, Komang Ariati dan Wiwik Susanah Rita \\ Program Studi Kimia FMIPA Universitas Udayana, Bukit Jimbaran, Badung, Bali 80361 \\ *Email: rustini.nilih@yahoo.co.id
}

\begin{abstract}
ABSTRAK
Pada penelitian ini dipelajari efek ekstrak etanol biji jagung (Zea mays) terhadap profil lipid tikus wistar dengan diet tinggi lemak. Penelitian ini bertujuan untuk membuktikan efek antihiperkolesterolemia dari ekstrak etanol biji jagung dengan variasi dosis $50 \mathrm{mg} / \mathrm{Kg} \mathrm{BB} ; 100 \mathrm{mg} / \mathrm{Kg}$ BB dan $150 \mathrm{mg} / \mathrm{Kg}$ BB. Subjek penelitian ini ialah 24 ekor tikus Wistar yang dibagi menjadi 6 kelompok secara random dengan design penelitian posttest only control group design. Data hasil penelitian di analisis dengan uji tukey anova. Ekstrak etanol biji jagung dapat menurunkan kadar kolesterol total tikus wistar dengan diet tinggi lemak dengan dosis $50 \mathrm{mg} / \mathrm{Kg} \mathrm{BB}, 100 \mathrm{mg} / \mathrm{Kg} \mathrm{BB}$ dan 150 $\mathrm{mg} / \mathrm{Kg}$ BB sebesar 5,44\%; 12,89\% dan 19,77\%. Kadar kolesterol LDL dapat diturunkan dengan dosis $50 \mathrm{mg} / \mathrm{Kg}$ BB, $100 \mathrm{mg} / \mathrm{Kg}$ BB dan $150 \mathrm{mg} / \mathrm{Kg}$ BB sebesar 2,55\%; 8,74\% dan 15,66\%. Kadar kolesterol HDL dapat ditingkatkan dengan dosis $50 \mathrm{mg} / \mathrm{Kg} \mathrm{BB}, 100 \mathrm{mg} / \mathrm{Kg} \mathrm{BB}$ dan $150 \mathrm{mg} / \mathrm{Kg}$ BB sebesar 1,5\%; 2,08\% dan 3,24\%. Hasil uji fitokimia menunjukkan bahwa ekstrak etanol biji jagung positif mengandung senyawa golongan steroid dan fenol. Senyawa tersebut memiliki aktivitas antioksidan dan dapat meningkatkan antioksidan endogen di dalam tubuh, sehingga dapat menurunkan kolesterol darah.
\end{abstract}

Kata kunci: biji jagung, fenol, HDL, kolesterol total, LDL, steroid

\begin{abstract}
This paper reports the effects of ethanol extract of corn (Zea mays) on the lipid profile Wistar rats with high-fat diet. This study aimedto prove antihiperkolesterolemia effect of ethanol extract of corn with a variation of doses, namely $50 \mathrm{mg} / \mathrm{kg} ; 100 \mathrm{mg} / \mathrm{kg}$ and $150 \mathrm{mg} / \mathrm{kg}$ of BW. The subjects of this study were 24 Wistar rats divided into 6 groups randomly with a research design of posttest only control group design. The data was analyzed with ANOVA Tukey test. The ethanol extract of corn could reduce the total cholesterol of Wistar rats with high-fat diet with a dose of $50 \mathrm{mg} / \mathrm{kg}, 100 \mathrm{mg} / \mathrm{kg}$ and $150 \mathrm{mg} / \mathrm{kg}$ of BW as much as $5.44 \% ; 12.89 \%$ and $19.77 \%$, respectively. The LDL could be lowered with the doses of $50 \mathrm{mg} / \mathrm{kg}, 100 \mathrm{mg} / \mathrm{kg}$ and $150 \mathrm{mg} / \mathrm{kg}$ of BW by $2.55 \% ; 8.74 \%$ and $15.66 \%$, respectively. The HDL levels could be increased with the doses of $50 \mathrm{mg} / \mathrm{kg}, 100 \mathrm{mg} / \mathrm{kg}$ and $150 \mathrm{mg} / \mathrm{kg} \mathrm{of}$ BW by $1.5 \% ; 2.08 \%$ and $3.24 \%$, respectively. The results of phytochemical test showed that the ethanol extract of corn contained steroids and phenolic compounds. This compounds has antioxidant activity and may increase endogen antioxidant in the body, so that it can lower blood cholesterol.
\end{abstract}

Keywords: corn, HDL, LDL, phenolic, steroids, total cholesterol

\section{PENDAHULUAN}

Penyakit jantung koroner merupakan penyebab kematian utama di dunia. Pada tahun 2003, di Inggris lebih dari 114.000 orang meninggal akibat penyakit jantung koroner. Diperkirakan pada tahun 2020, sebesar $36 \%$ dari kematian disebabkan oleh penyakit tersebut (Rofida, et al., 2015). Keadaan profil lipid yang tidak normal ditunjukkan dengan peningkatan kolesterol total, kolesterol LDL (Low Density Lipoprotein) dan penurunan kolesterol HDL (High Density Lipoprotein) merupakan faktor risiko kuat penyakit jantung koroner (Heryani, 2016).

Penyakit jantung koroner disebabkan oleh penyempitan pembuluh arteri yang mengalirkan darah ke otot jantung yang dikenal sebagai arterosklerosis. Arterosklerosis disebabkan oleh adanya endapan lemak dan kolesterol di sepanjang dinding arteri. Di dalam darah kolesterol diangkut 
dalam bentuk lipoprotein. LDL merupakan komponen utama yang menyebabkan peningkatan risiko arterosklerosis. LDL merupakan lipoprotein pengangkut kolesterol terbesar pada manusia yang berfungsi mengangkut sebagian besar kolesterol darah dari hati ke jaringan (Wurdianing, et al., 2014). Asupan lemak jenuh dan kolesterol yang tinggi dapat meningkatkan kadar kolesterol plasma (Anwar, 2004).

Penurunan kadar kolesterol dapat dilakukan dengan diet, olah raga atau dengan mengkonsumsi obat-obatan hipolipidemia. Penggunaan obat tradisional hipolipidemia telah banyak dilakukan oleh masyarakat Indonesia. Selain murah dan mudah didapat juga memiliki efek samping yang kecil sehingga relatif aman jika dibandingkan dengan obat-obat sintetis (Wahyuni, et al., 2013).

Pemberian dekok rambut jagung (Zea mays) dosis $7,7 \mathrm{~mL} /$ hari berpengaruh sangat nyata terhadap penurunan kadar kolesterol total, trigliserida dan kolesterol LDL serta meningkatkan kadar kolesterol HDL tikus yang diberi diet tinggi lemak (Utariningsih, 2007). Rambut jagung memiliki kandungan kimia seperti senyawa fenol, flavonoid, alkaloid, saponin, tanin dan alantoin (Suarni dan Subagio, 2013). Saponin berfungsi mengikat kolesterol dengan asam empedu sehingga dapat menurunkan kadar kolesterol darah. Senyawa fenol dan flavonoid bersifat sebagai antioksidan yang berperan terhadap mekanisme perbaikan profil lipid (Clementine, 2013). Kandungan senyawa kimia akan terdistribusi pada seluruh bagian tanaman, sehingga kemungkinan biji jagung juga memiliki kandungan kimia yang hampir sama dengan rambut jagung. Penelitian penggunaan biji jagung (Zea mays) dalam menurunkan kadar kolesterol belum pernah dilakukan, sehingga dalam penelitian ini akan diuji kemampuan ekstrak etanol biji jagung dalam menurunkan kadar kolesteroL total, Low Density Lipoprotein (LDL) serta meningkatkan High Density Lipoprotein (HDL).

\section{Bahan}

\section{MATERI DAN METODE}

Bahan yang digunakan dalam penelitian ini meliputi biji jagung (Zea mays), etanol $96 \%$, tikus putih (Rattus norvegicus) jantan galur Wistar berumur 10 minggu dengan berat awal 180-200 gram, pakan standar, air minum, air suling, simvastatin, kit pemeriksaan total kolesterol, LDL, HDL (merek Thermo), kuning telor puyuh dan lemak sapi sebagai pakan tinggi lemak.

\section{Peralatan}

Alat yang digunakan dalam penelitian ini adalah: seperangkat alat gelas, blender, ayakan, rotary vacum evaporator, sentrifuge, neraca analitik, pipet tetes, pipet mikro, sonde lambung, syringe, tabung eppendorf, dan spektrofotometer UV-vis.

\section{Cara Kerja \\ Preparasi Sampel}

Sampel segar biji jagung (Zea mays.) dicuci menggunakan air, dikeringkan dengan cara diangin-anginkan, tanpa terkena sinar matahari. Sampel biji jagung yang telah kering selanjutnya dihaluskan dan ditimbang dengan neraca analitik.

\section{Ekstraksi Biji Jagung}

Sebanyak $1000 \mathrm{~g}$ serbuk kering biji jagung dimaserasi dengan etanol 96\% selama $3 \mathrm{x}$ 24 jam, lalu disaring. Ekstrak etanol kemudian dipekatkan dengan rotary vacuum evaporator, sehingga didapatkan ekstrak pekat etanol.

\section{Uji Fitokimia}

Identifikasi senyawa fenol dilakukan dengan cara mereaksikan $1 \mathrm{~mL}$ ekstrak etanol biji jagung dengan 3 tetes larutan $\mathrm{FeCl}_{3}$. Adanya perubahan warna menjadi ungu kehitaman menunjukkan adanya senyawa fenol

Identifikasi senyawa flavonoid dilakukan dengan mereaksikan $1 \mathrm{~mL}$ ekstrak etanol biji jagungdengan serbuk $\mathrm{Mg}$ dan $1 \mathrm{~mL} \mathrm{HCl}$ pekat. Adanya perubahan warna menjadi merah menunjukkan adanya senyawa flavonoid.

Identifikasi senyawa steroid dilakukan dengan mereaksikan $1 \mathrm{~mL}$ ekstrak etanol biji jagung dengan beberapa tetes asam asetat anhidrat dan asam sulfat pekat (pereaksi LiebermanBurchard). Perubahan warna yang terjadi diamati. Adanya steroid diawali dengan terbentuknya endapan merah yang secara bertahap berubah menjadi biru atau hijau.

\section{Perlakuan Hewan Uji}

Hewan uji tikus Wistar jantan diadaptasi selama 1 minggu dengan pemberian pakan standar 
dan air minum secara ad libitum. Setelah proses aklimatisasi, hewan uji dibagi menjadi 6 kelompok. Masing-masing kelompok terdiri dari 4 ekor tikus, sehingga total tikus sebanyak 24 ekor. Kelompok kontrol negatif (K1) hanya diberi pakan standar dan air minum secara ad libitum. Kelompok kontrol positif (K2) diberikan diet tinggi lemak selama 15 hari, kemudian dilanjutkan dengan pemberian pakan standar dan air minum secara ad libitum selama 30 hari. Kelompok perlakuan (P1, P2, dan P3) diberikan diet tinggi lemak selama 15 hari kemudian dilanjutkan dengan pemberian ekstrak biji jagung dengan dosis 50,100 , dan $150 \mathrm{mg} / \mathrm{kgB}$ selama 30 hari. Kelompok perlakuan P4 diberikan diet tinggi lemak selama 15 hari yang dilanjutkan dengan pemberian simvastatin $20 \mathrm{mg} / \mathrm{kgBB}$ selama 30 hari. Diet tinggi lemak dibuat dengan mencampurkan lemak sapi dan kuning telur puyuh (1:5) ke dalam pakan standar. Pada hari ke 46 dilakukan pengambilan darah dari pleksus retroorbitalis. Parameter pengujian profil lipid terdiri dari total kolesterol, LDL kolesterol dan HDL kolesterol.

Uji beda profil lipid antara kelompok perlakuan menggunakan uji one way anova. Apabila hasilnya signifikan maka dilanjutkan analisis dalam kelompok perlakuan menggunakan uji Turkey.

\section{HASIL DAN PEMBAHASAN}

\section{Ekstraksi Biji Jagung}

Ekstraksi $\pm 1000 \mathrm{~g}$ serbuk biji jagung dengan $6000 \mathrm{~mL}$ etanol $96 \%$ menghasilkan 46,70 g ekstrak pekat etanol yang berwarna kuning tua. Ekstrak pekat etanol yang diperoleh kemudian diidentifikasi dengan uji fitokimia dan diuji kemampuannya dalam menurunkan kolesterol total, kolesterol LDL dan meningkatkan kolesterol HDL tikus wistar dengan diet tinggi lemak.

\section{Identifikasi Ekstrak Etanol Biji Jagung dengan Uji Fitokimia}

Uji fitokimia dilakukan dengan menambahkan pereaksi fitokimia ke dalam ekstrak etanol biji jagung. Hasil uji fitokimia dapat dilihat pada Tabel 1.

Data pada Tabel 1 menunjukkan bahwa ekstrak etanol biji jagung positif mengandung senyawa golongan fenolik dan steroid.

\section{Profil Lipid Tikus yang Diberi Ekstrak Biji Jagung}

Ekstrak etanol biji jagung (Zea mays) dapat menurunkan kadar kolesterol total tikus wistar dengan dosis $50 \mathrm{mg} / \mathrm{Kg} \mathrm{BB}, 100 \mathrm{mg} / \mathrm{Kg} \mathrm{BB}$ dan $150 \mathrm{mg} / \mathrm{Kg} \mathrm{BB}$ sebesar 5,44\%; 12,89\% dan $19,77 \%$. Kadar kolesterol LDL dapat diturunkan dengan dosis $50 \mathrm{mg} / \mathrm{Kg} \mathrm{BB}, 100 \mathrm{mg} / \mathrm{Kg} \mathrm{BB}$ dan $150 \mathrm{mg} / \mathrm{Kg}$ BB sebesar 2,55\%; 8.74\% dan $15,66 \%$. Kadar kolesterol HDL dapat ditingkatkan dengan dosis $50 \mathrm{mg} / \mathrm{Kg} \mathrm{BB}, 100 \mathrm{mg} / \mathrm{Kg}$ BB dan 150 $\mathrm{mg} / \mathrm{Kg}$ BB sebesar 1,5\%; 2,08\% dan 3,24\%. Perubahan profil lipid tikus selama 45 hari masa pemeliharaan dengan perlakuan diet yang berbeda dapat dilihat pada Gambar 1.

Tabel 1. Hasil Uji Fitokimia

\begin{tabular}{cllll}
\hline No & \multicolumn{1}{c}{$\begin{array}{c}\text { Uji fitokimia untuk } \\
\text { senyawa }\end{array}$} & \multicolumn{1}{c}{ Pereaksi } & Perubahan warna & \multicolumn{1}{c}{ Kesimpulan } \\
\hline 1 & Flavonoid & Wilstater & Tidak ada perubahan & - \\
2 & Fenolik & $\mathrm{FeCl}_{3}$ & Ungu & + (fenolik) \\
3 & Steroid/triterpenoid & Lieberman-Burchard & Biru kehijauan & + (steroid) \\
\hline
\end{tabular}




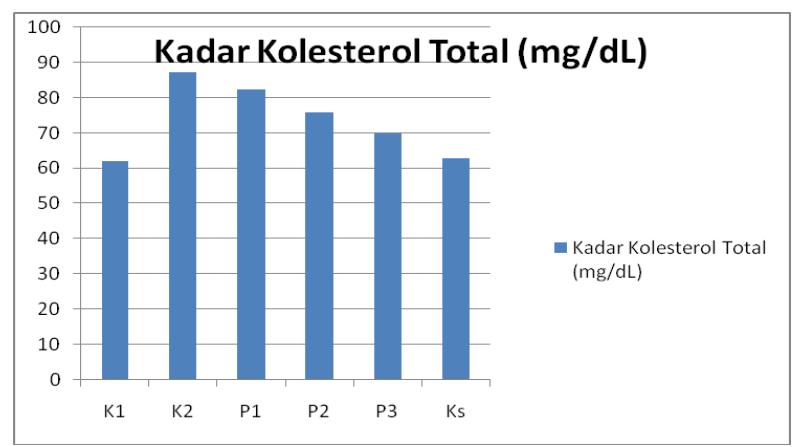

(a)

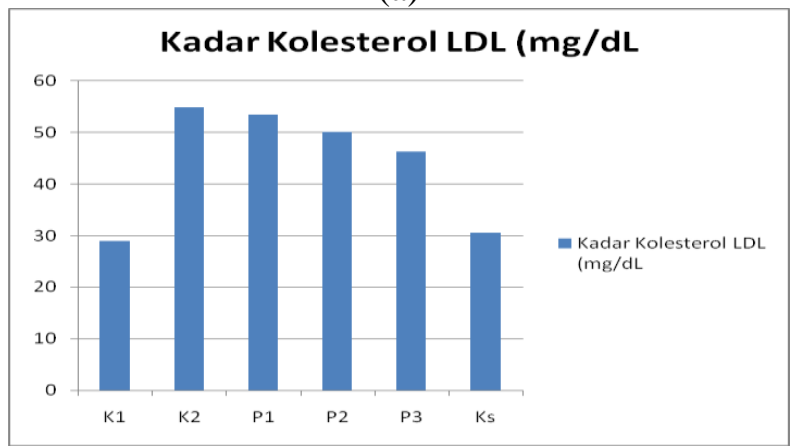

(b)

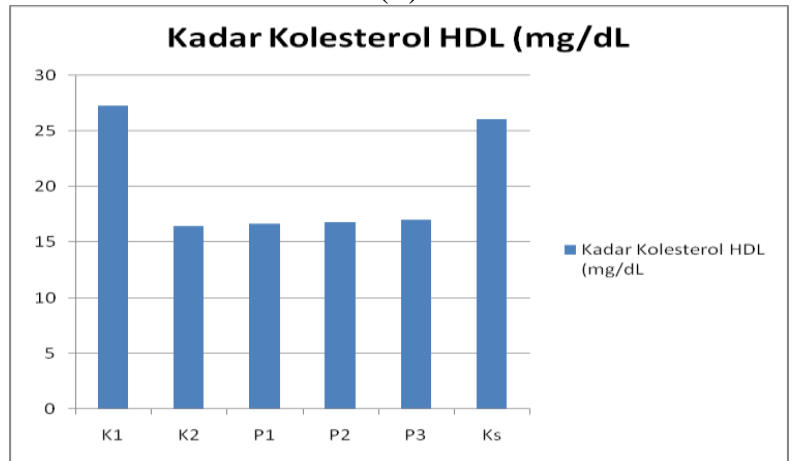

(c)

Gambar 1. Profil lipid tikus Wistar sesudah perlakuan : (a) Kolesterol total, (b) Kolesterol LDL, (c) Kolesterol HDL

Keterangan :

$$
\begin{aligned}
\mathrm{K} 1= & \text { Kelompok kontrol negatif } \\
\mathrm{K} 2= & \text { Kelompok kontrol positif } \\
\mathrm{P} 1= & \text { eemberian ekstrak etanol biji jagung } \\
& \text { dosis } 50 \mathrm{mg} / \mathrm{kg} \mathrm{BB} \\
\mathrm{P} 2= & \text { Kelompok pemberian ekstrak } \\
& \text { etanol biji jagung dosis } 100 \mathrm{mg} / \mathrm{kg} \\
& \mathrm{BB} \\
\mathrm{P} 3= & \text { Kelompok pemberian ekstrak } \\
& \text { etanol biji jagung dosis } 150 \mathrm{mg} / \mathrm{kg} \\
& \mathrm{BB} \\
\mathrm{Ks}= & \begin{array}{l}
\text { Kelompok pemberian obat } \\
\text { simvastatin dosis } 200 \mathrm{mg} / \mathrm{kg} \mathrm{BB}
\end{array}
\end{aligned}
$$

Hasil analisa menggunakan Anova terhadap kadar kolesterol total, kolesterol HDL dan kolesterol LDL menunjukkan bahwa terdapat perbedaan yang bermakna pada setiap kelompok perlakuan. Hasil analisa dengan uji Tukey terhadap kadar kolesterol total menunjukkan bahwa hanya kelompok kontrol negatif (K1) dengan kelompok tikus yang diberi obat simvastatin (Ks) yang tidak berbeda secara bermakna. Hasil analisa dengan uji Tukey terhadap kadar kolesterol HDL menunjukkan bahwa kelompok-kelompok yang tidak berbeda secara bermakna adalah kelompok K2 dengan P1 dan P2, kelompok P1 dengan P2 dan P3, dan kelompok P2 dengan P3. Hasil analisa uji Tukey terhadap kadar kolesterol LDL menunjukkan adanya perbedaan yang bermakna pada setiap kelompok perlakuan.

Penurunan kadar kolesterol tikus yang diberi ekstrak etanol biji jagung diduga disebabkan oleh senyawa fenolik, steroid, serat dan vitamin E yang terkandung di dalam ekstrak tersebut yang bekerja secara sinergis. Fenol atau polifenol menurunkan kolesterol LDL dengan berbagai cara seperti mencegah penyerapan, biosintesis LDL, menurunkan jumlah apolipoprotein B-100, dan sebagai antioksidan menurunkan kadar LDL yang teroksidasi. Mekanisme peningkatan kadar HDL oleh fenol yakni dengan meningkatkan proses reverse cholesterol transport (RCT) oleh makrofag.

Senyawa fenolik diketahui memiliki aktivitas antioksidan. Senyawa fenolik dapat bereaksi dengan radikal bebas melalui penangkapan langsung terhadap radikal bebas oksigen dan menginhibisi enzim penyebab terbentuknya radikal bebas seperti siklooksigenase dan lipooksigenase. Dalam menurunkan kadar kolesterol, senyawa antioksidan tersebut diduga bekerja dengan cara menghambat enzim HMG-CoA reduktase yang berfungsi sebagai katalis dalam pembentukan kolesterol dan meningkatkan aktivitas Lechitin Cholesterol Acyl Transferase (LCAT). LCAT merupakan enzim yang dapat mengubah kolesterol bebas menjadi ester kolesterol membentuk HDL baru. Hal ini akan meningkatkan kadar HDL serum. Penghambatan terhadap HMG-CoA reduktase menyebabkan penurunan sintesis kolesterol dan meningkatkan jumlah reseptor LDL yang terdapat dalam membran sel hati dan jaringan 
ekstrahepatik, sehingga kadar kolesterol total dan LDL dalam plasma turun (Heriyani, 2016).

Penurunan kadar kolesterol tikus juga disebabkan oleh adanya kandungan senyawa sterol dalam ekstrak biji jagung. Senyawa sterol yang terkandung dalam tumbuh-tumbuhan disebut dengan fitosterol. Fitosterol dapat menurunkan kadar kolesterol darah melalui dua mekanisme. Pertama, fitosterol menghambat penyerapan kolesterol dari makanan sehingga mereduksi kadarnya di dalam darah. Kedua, fitosterol juga menghambat reabsorpsi (penyerapan kembali) kolesterol dari hati. Kedua mekanisme tersebut secara khusus dapat mereduksi kadar kolesterol di dalam darah. Selain mekanisme penghambatan absorpsi, kehadiran fitosterol juga dapat menghindari kolesterol di dalam garam empedu, meningkatkan eskresi garam empedu atau menghindari esterifikasi kolesterol di dalam mukosa internal (Nurdin, et al., 2014).

Jagung mengandung serat untuk menurunkan kolesterol, dan juga kaya akan asam folat yang berperan menurunkan kadar homosistein dalam pembuluh darah. Homosistein merupakan suatu jenis asam amino yang bila kadarnya meningkat di dalam darah dapat merusak pembuluh darah sehingga meningkatkan serangan jantung dan stroke (Suarni dan Subagio, 2013).

Penurunan kadar kolesterol total dan kolesterol LDL juga terjadi pada kelompok pembanding yang diberi simvastatin. Simvastatin juga memiliki mekanisme antikolesterol dengan menghambat secara kompetitif enzim HMG-CoA reduktase yang berfungsi sebagai katalis dalam pembentukan kolesterol (Becker, 2005).

\section{SIMPULAN DAN SARAN}

\section{Simpulan}

Berdasarkan hasil penelitian yang telah dilakukan dapat disimpulkan bahwa ekstrak etanol biji jagung mengandung senyawa golongan fenol dan steroid. Ekstrak tersebut dapat menurunkan kadar kolesterol total tikus wistar yang diberi diet tinggi lemak dengan dosis $50 \mathrm{mg} / \mathrm{Kg} \mathrm{BB}, 100$ $\mathrm{mg} / \mathrm{Kg} \mathrm{BB}$ dan $150 \mathrm{mg} / \mathrm{Kg}$ BB sebesar 5,44\%; $12,89 \%$ dan $19,77 \%$. Kadar kolesterol LDL dapat diturunkan dengan dosis $50 \mathrm{mg} / \mathrm{Kg} \mathrm{BB}, 100$ $\mathrm{mg} / \mathrm{Kg} \mathrm{BB}$ dan $150 \mathrm{mg} / \mathrm{Kg} \mathrm{BB}$ sebesar 2,55\%;
$8,74 \%$ dan $15,66 \%$. Kadar kolesterol HDL dapat ditingkatkan dengan dosis $50 \mathrm{mg} / \mathrm{Kg} \mathrm{BB}, 100$ $\mathrm{mg} / \mathrm{Kg} \mathrm{BB}$ dan $150 \mathrm{mg} / \mathrm{Kg} \mathrm{BB}$ sebesar 1,5\%; $2,08 \%$ dan $3,24 \%$.

\section{Saran}

Perlu adanya penelitian lebih lanjut untuk mengetahui komponen senyawa kimia yang terkandung dalam ekstrak etanol biji jagung yang mampu menurunkan kadar kolesterol total, kolesterol LDL dan meningkatkan kolesterol HDL.

\section{UCAPAN TERIMA KASIH}

Penulis mengucapkan terima kasih kepada seluruh staff UPT. Laboratorium Analitik Universitas Udayana dalam membantu kelancaran penelitian ini Pada kesempatan ini, penulis menyampaikan terimakasih banyak kepada semua pihak yang turut serta membantu dalam proses penyelesaian penelitian ini.

\section{DAFTAR PUSTAKA}

Becker, D.J., 2005, Simvastatin vs Therapeutic Lifestyle Change and Supplements Randomized Primary Prevention Trial, Mayo Clin Proc, 7 (2): 758-764

Bonsdorff, N. and Anna, V., 2005, Studies on Cholesterol-Lowring Microcrystallin Phytosterol Suspension in Oil, Faculty of Pharmacy of the University of Helsinki, Helsinki

Clementine, R., 2013, Uji Efektivitas ekstrak Flavonoid dan Steroid dari Gedi (Abelmochus manihot) sebagai anti Obesitas dan Hipolipidemik pada Tikus Putih Jantan galur Wistar, Jurnal Ilmiah Farmasi - UNRAT, 2 (20): 230-249

Diass, W. C. dan Estiasih, T., 2015, Pengaruh Senyawa Bioaktif Umbi-Umbian Keluarga Dioscoreaceae terhadap Kondisi Profil Lipid Darah: Kajian Pustaka, Jurnal Pangan dan Agroindustri, 3 (2): 424-430

Fikri, F., 2009, Bahaya Kolesterol, Katahati, Yogyakarta

Harbone, J.B., 1987, Metode Fitokimia: Penuntun Cara Modern Menganalisis Tumbuhan, Jilid II, ITB, Bandung 
Heriansyah, T., 2013, Pengaruh Berbagai Durasi Pemberian Diet Tinggi Lemak terhadap Profil Lipid Tikus Putih (Rattus novergicus) Jantan, Jurnal Kedokteran Syah Kuala, 13 (3): 144-150

Heryani, R., 2016, Pengaruh Ekstrak Buah Naga Merah terhadap Profil Lipid Darah Tikus Putih Hiperlipidemia, Jurnal IPTEKS Terapan, 10 (2): 68-77

Heyne, K., 1987, Tumbuhan Berguna Indonesia, Jilid 1, Cetakan I, Badan Litbang Kehutanan, Ruygrok \& Co., Jakarta

Lehninger, 1982, Dasar-Dasar Biokimia, Jilid 1, Erlangga, Jakarta

Moreau, R. A., 2002, Phytosterols, Phytostanols and Their Conjugates in Food Structural Diversity, Quantitative Analysis, and Health Promoting Uses, Progress in Lipid Research, 41: 475-500

Nurdin, N. M., Rimbawan, Martianto, D., dan Dewi, M., 2014, Pengaruh Intervensi Penambahan Fitosterol pada minyak Goreng Sawit terhadap Profil Lipid Subjek dengan Sindroma Metabolik, Jurnal Gizi dan Pangan, 9 (2): 81-88

Rofida, S., Firdiansyah, A., dan Fitriyastuti, E., 2015, Aktivitas Antihiperlipidemia Ekstrak Etanol Daun Annona squamosa L., Journal of Pharmaceutical Science and Pharmacy Practice, 2 (1): 1-5

Suarni dan Subagio, S., 2013, Potensi Pengembangan Jagung dan Sorgum sebagai Sumber Pangan Fungsional, $J$. Litbang Pert, 32 (2): 47-55

Subekti, S., 2006, Penggunaan Tepung Daun Katuk dan Ekstrak Daun Katuk (Sauropus androgynus L.) sebagai Substitusi Ransum yang Dapat Menghasilkan Produk Puyuh Jepang Rendah Kolesterol, J. ITV., 11 (4): 254-259

Utariningsih, D., 2007, Dekok rambut Jagung (Zea mays L.) Efektif dalam Menurunkan Kadar Kolesterol Tikus Putih, Universitas Muhammadiyah, Malang

Wahyuni, F. D., Asyiah, L. N., dan Hariyadi, S., 2013, Pengaruh Ekstrak n-Heksana Daging Buah Delima Putih (Punica granatum) terhadap Penurunan Kadar Kolesterol Darah pada Tikus Putih, Jurnal Pancaran, 2 (4): 89-99

Wurdianing, I., Nugraheni, S. A., dan Rahfiludin, Z., 2014, Efek Ekstrak Daun Sirsak (Annona muricata L.) terhadap Profil Lipid Tikus Putih Jantan (Rattus novergicus), Jurnal Gizi Indonesia, 3 (1): 7-12

Zaki, I., Johan, A., dan Suci, N. W., 2015, Pengaruh Pemberian Jus Mangga terhadap Profil Lipid dan Malondialdehida Tikus yang Diberi Minyak Jelantah, Jurnal Gizi Indonesia, 3 (2): 108-115 